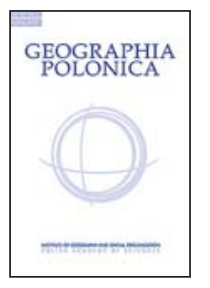

\title{
CULTURAL SECTOR ENTITIES IN WROCŁAW
}

\section{Beata Namyślak}

\author{
Institute of Geography and Regional Development \\ University of Wrocław \\ pl. Uniwersytecki 1, 50-137 Wrocław: Poland \\ e-mail: beata.namyslak@uwr.edu.pl
}

\begin{abstract}
The present article deals with issues of cultural economics. The author sought to characterise cultural sector entities in Wrocław (Poland). The study is based on a statistical analysis of data from the Central Statistical Office (GUS) which characterise the cultural sector in Poland and in the studied city in 2010-2019. Special focus was given to provide the characteristics of the entities, including their number, number of employees, type of activity and spatial distribution. Based on the information collected, the author has formulated the following conclusions: recent years, especially the period 2016-2019, have witnessed a significant increase in the number of cultural entities, active especially in new media. Wrocław's cultural sector entities tend to be located in the vicinity of the Old Town and along the axis running from the city centre to the south, all the way to the municipality of Kobierzyce. The new trends observed in the development of culture do not build on the potential developed back in the 20th century, for instance in the film or television industry. In some areas (including publishing, radio, television) one can observe intense competition from entities (both domestic and foreign) located in other cities, mainly in Warsaw. No single creative activity is prevailing in Wrocław, which means that the city has not yet selected its specialisation in the field of culture.
\end{abstract}

\section{Key words}

cultural sector $\cdot$ creative industries - Wrocław $\cdot$ Poland

\section{Introduction}

Culture is currently one of the basic development factors in such areas as intellectual capital and economic development. It increases the attractiveness of cities for residents, investors and tourists as well as their importance within their respective spatial, economic and social systems (Evans, 2009; Landry, 2000; Trip \& Romein, 2014). Areas with a high concentration of creative industries, including the cultural sector, are characterised by a high standard of living and high patent ratio being a derivative of the presence of creators of intellectual property, in particular copyright (Power, 2011). Culture also plays an important role in social issues. It plays an important role in maintaining the identity of the local community, its creativity and internal cohesion. 
The present paper is a contribution to cultural economics research. The reason behind the choice of the cultural sector as the subject of research is the scarce number of studies on the topic as well as still too low prestige associated with cultural activities. And yet, through the products and services it offers, the cultural sector shapes social attitudes and contributes to the creation of development stimuli at the interface of culture and business.

The selected research area is Wrocław, a city with a population exceeding 640 thousand (2018) and the capital of the Lower Silesian (Dolnoślaskie) voivodeship (NUTS 2). The goal of the paper was to characterise cultural sector entities in Wrocław, taking into account their number, year of establishment, number of employees and type of activity conducted. Spatial distribution of the analysed entities within the city has been presented and the development opportunities for individual types of cultural sector activities have been outlined. The author attempted to answer the following questions: (1) does the cultural sector in Wrocław draw and build on the achievements of the 20th century for example in the area of film or TV, and (2) has Wrocław developed any specialisation in the sphere of culture? It has also proved important to find answers to a number of detailed questions, such as: (1) what are the regularities in the distribution of cultural sector entities in Wrocław, (2) what is the share of foreign capital in cultural sector entities operating in the Wrocław market, and (3) which of the analysed types of activity show the highest growth in terms of the number of entities? As a general goal, the author sought to collect current data and observations related to the entities of the cultural sector, the sector which is gaining increasing importance in the capital of Lower Silesia. Wrocław has already won the titles of European Capital of Culture in 2016 and UNESCO Creative City in the field of literature in 2019. The cultural infrastructure has improved, the number of cultural events has increased, as well as the participation of residents in the cultural life of the city. With this paper, the author intends to contribute to the knowledge of the topic. To do it, the author presents a characteristics of cultural entities in Wrocław in order to determine the city's resources in the field. The paper relies on a set of dynamic statistical data, which additionally distinguishes the study from other papers devoted to culture in Poland. No analysis of this level of detail has yet been published in scientific journals.

\section{Cultural sector as a part of cultural industries - theoretical approach}

In the literature on the subject, the creative knowledge sector of economy is the one that comprises activities based on intellectual property, rooted in culture and science. The above sector comprises two main groups: creative industries and the so-called knowledge intensive industries. Researchers of creative industries most often quote studies by the British Department of Culture, Media and Sport (DCMS) (e.g. 2013) according to which creative industries include those sectors that are based on human creativity, which produce and use intellectual property and also have a potential for job and wealth creation. According to DCMS, creative industries include: advertising, publishing, photography, architecture, art and antiques market, radio and $T V$, film and video, music, graphic and fashion design, performing and visual arts, crafts, software and computer services as well as video and computer games. Some researchers (Kong, 2000) regard sport and recreation as parts of creative activities, while others include only recreation in this category (Stryjakiewicz \& Stachowiak, 2010). In some sources, cultural tourism is also considered a part of creative industries (UNESCO, 2009). If a copyright protected new quality is chosen as the basic indicator of creativity, then trade in antiques (Jankowska, 2012) or cultural tourism are excluded. In addition, one can observe different names given to some components, which in practice means either extension or narrowing of the problem, 
e.g. cultural heritage sometimes is used to mean architecture.

The term 'cultural sector' is used with regard to selected creative activities. This sector includes museums, galleries, libraries, as well as crafts, visual arts, film, radio, performing arts (such as theatre, opera) and literature (KEA, 2006 October). Therefore, culture comprises traditional fields of art producing outputs having artistic value, while creative industries also include activities that use culture as an added-value for the production of non-cultural products (i.e. Flew \& Cunningham, 2010; Garnham, 2005; Stryjakiewicz, Męczyński \& Stachowiak, 2014; Throsby, 2008; Towse, 2010).

Within cultural industries there is a distinction between activities dealing with the manufacturing of products and the provision of services. Therefore, one can distinguish publishing activities, music or film, which focus on the production of goods such as books, CDs/records, magazines, video recordings and films. The second group includes museums, art galleries, libraries, cinemas, theatres, philharmonic halls or institutions providing audiovisual services (distribution of films, TV programmes, etc.), whose purpose is to provide services in the field of culture (Gibson, 2010). The products of the cultural sector can be copied, they are reproducible and can be disseminated. The above promotes media convergence, i.e. a situation in which one product can be distributed using a variety of media. For example, a film can be watched in the cinema, on television, on a tablet, computer, smartphone or it may be played from a DVD or Blu-ray disc (Flew, 2013; Cooke \& Porter, 2011; Stachowiak, 2017). On the other hand, some of the services, such as an opera performance or a music concert are unique goods and are consumed 'on the spot'. These are instances where music, sound and image offer specific artistic impressions, which in turn lead to the development of "experience economy" (Pine \& Gilmore, 1999; Kacprzak, Dziewianowska, \& Skorek, 2015). Nevertheless, both cultural products and cultural services have the same goal - to convey content, symbols or to exert a broadly understood impact on lifestyles and social attitudes (Pratt, 2008).

Apart from classifications taking into account outputs of various activities, one can also group cultural industries by sources of funding. One can distinguish culture financed from the central budget, with its financial situation on the market dependent on the current cultural policy and on the income from other GDP generating economy sectors. The other group of entities is selffinancing, which means that the cultural goods and services they produce are clearly market-oriented. In real life, one can find entities functioning as a mix of the abovementioned models (Fig. 1), which at the same time try to seek new sources of financing, for example from non-profit organisations or from lotteries. However, looking at culture as a whole, it should be assumed that both cultural goods and cultural services are market goods that have value and are subject

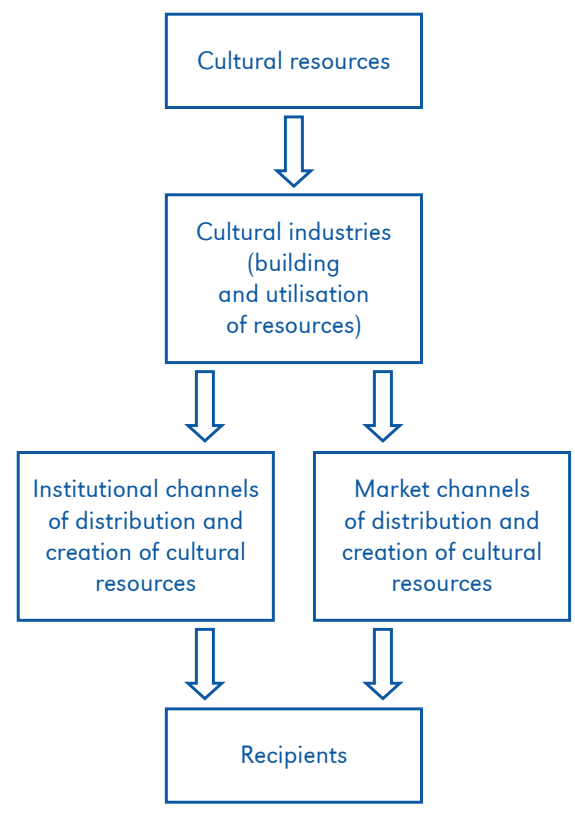

Figure 1. Process of utilising cultural resources Source: Own study based on Kościelecki, 2007. 
to the classic laws of supply and demand (Blaug, 2001)'.

This study is devoted to cultural sector entities, both those funded by the central government and private ones. The number of such entities is, in accordance with the literature on the subject, one of the conditions for a creative city (Florida, 2002; Hospers, 2003; Klasik, 2011; Landry, 2008). Such city is characterised by the presence of human capital, that is a certain highly-skilled part of society working in some strictly specified professions and also by the presence of businesses established in response to the new economy based on creative industries. Other features of a creative city mentioned in the definitions by various authors are: the quality of space, especially the factors considered by residents/entrepreneurs to be decisive in choosing a place to live/invest, technological infrastructure, i.e. investments in hard and soft projects, offering a strategic advantage, as well as cultural capital or city governance. Innovation and modern technologies are taken for granted - as processes that occur in the economy regardless of structural transformations.

\footnotetext{
1 Many theoreticians of economics expressed their views on culture funding system. Among them, John Maynard Keynes (1883-1946) saw the role of subsidy to the arts as boosting market supply and demand as a temporary measure; Keynes believed that it should be used only until the quality of the arts is raised sufficiently to make them accessible throughout the country. Ultimately however, culture should be self-financing. John Kenneth Galbraith (1908-2006) put forward the view that economics has nothing to say about the arts. He regarded the arts as 'exceptional' - that is, not like other economic goods - because they are produced by 'artisan' methods rather than being mass-produced, and therefore cultural development should receive government support. Lionel Robbins (1898-1984) also advocated the public patronage of national heritage. He believed that "art brings collective benefits to the entire society". The first serious attempt at applying the methods of economic analysis to the problems connected with funding creative activities was a book by W. Baumol and W. Bowen titled Performing Arts: The Economic Dilemma, published in 1966. It discussed the so-called Baumol's cost disease, which boils down to the proposition that the arts need to be subsidised because the costs involved in artistic activity do not go down (as in many other sectors) along with technological progress.
}

\section{Current situation of the cultural sector in Poland}

Decentralisation of culture in Poland began in 1990 when municipal authorities took over some of the cultural institutions, mainly libraries, community centres and smaller museums. The beginning of political transformation was also the time of privatisation of the publishing and music market. The second stage of decentralisation took place at the turn of 1998 and 1999. It was a result of the new administrative reform of 1999 which introduced a three-tier territorial division into voivodeships (NUTS 2), poviats (LAU 1) and municipalities (LAU 2). The newly created voivodeships took over a majority of the institutions formerly overseen by the Ministry of Culture and National Heritage, and previously non-existent poviats were put in charge of some of the facilities previously in the hands of voivodeship authorities. Currently, nearly all libraries, close to $90 \%$ of museums and about 55\% of art galleries and exhibition spaces are managed by government entities at various levels.

In Poland, public financing sources prevail over private ones. About three fourths of the spending of public entities in the cultural sector is funded by the central and local government. In recent years, foreign funds, mainly EU funds, have provided a significant cash injection. Some entities are funded privately, with such examples as the Old Brewery in Poznań, or the Cane Factory in Warsaw, which clearly indicate that there exist investors on the market who are willing and able to finance cultural projects. In the years 1995-2018, the share of cultural expenditure in Gross Domestic Product ranged from $0.41 \%$ to $0.94 \%$ (in recent years these shares have been increasing). However, the structure of spending is changing. In 2016, the largest share of expenditure from the central budget was allocated to investments and the functioning of museums (45.1\%) as well as to the protection of monuments and other forms of monument care $(10.3 \%)$. It was a continuation 
of the policy pursued in previous years. In 2017, expenditure on radio and television activities increased significantly (30.1\%), which resulted in smaller funding allocated for other purposes. However, in 2018 this structure changed again. The most was spent again on museums $(30.7 \%)$, as well as on radio and television (22.2\%), art and cultural centres (11.5\%) and monument protection (9.1\%) (Kultura..., 2017, 2018, 2019). In recent years, many cultural projects have been implemented across the country, with more than 200 hundred projects in 2012 alone. Priorities were given to: music, artistic and theatre schools, 'high culture' facilities in places previously deprived of them (for example Podlasie Opera in Białystok) and other innovative projects (such as construction of the Museum of Modern Art in Warsaw). The process of digitisation of the collection of the National Library, archives and photographs (National Digital Archives), theatre and music (National Audiovisual Institute) and national heritage (National Heritage Board of Poland) still remains a major challenge.

The market for individual cultural goods and services is characterised by different trends. In some cases, a positive trend can be observed (interest in a given service or cultural product increases), while in other cases the reverse is true. When comparing statistical data from 2005 to 2018 regarding the Polish cultural sector, several regularities can be seen, namely: the number of book titles published on the Polish market every year increases, as well as the number of libraries with Internet access. The number of museum visitors is on the rise (although it should be noted that the growth is largely owed to the increase in the number of free entrances, e.g. during the Museums Night), the number of cinema screening rooms is increasing mainly due to the construction of mini- and multiplexes, the number of screenings in cinemas and the number of viewers in cinemas and theatres goes up, along with the number of people visiting cultural centres to attend concerts, exhibitions or dance courses organised there. However, at the same time, the number of libraries shrank, mainly the smallest ones, the circulation of newspapers and magazines fell, along with the readership of libraries, especially in the pupils and students category. The number of theatre stages decreased, as well as the number of artistic performances abroad. These observations lead to the conclusion that overall, interest in the cultural offer is growing. However, the infrastructure of the sector is undergoing changes. Small cinemas, theatres and libraries are closed, giving way to large, modern facilities. In terms of quantity, a decline is observed in several categories, although the capacities for serving the recipients of culture in the new facilities are increasing. Print newspapers and magazines are squeezed out of the market by their online versions. Probably, this process cannot be stopped (especially that in 2019 VAT for online dailies and magazines was reduced to $8 \%$ and for e-books to $5 \%$ ).

Every year, the Central Statistical Office calculates the average value of a Polish household spending on culture. In recent years, it has been about PLN 350, roughly an equivalent of $€ 82$ (for comparison, in 2018 it was PLN 356.40). In accordance with EU statistical definitions, this value comprises both subscription fees (e.g. cable TV subscription fees account for as much as $26 \%$ of the total expenditure), purchase costs of TV sets, DVD players and of other audiovisual equipment, as well as costs of purchasing tickets to cultural institutions. In 2018, the average per capita spending on tickets to theatres, cinemas and musical institutions was less than PLN 34.80, which, taking into account market prices, corresponds to two cinema tickets or one theatre ticket. Average expenditure on books (excluding handbooks) was PLN 24 (which is not enough to purchase a new title on the market), while the average annual spending on newspapers and magazines was PLN 26.40 (this segment is dominated by entertainment press including TV guides).

It should be added, however, that there are also other processes occurring across the country of a sociological, economic and spatial nature. For instance, in the field 
of education, the number of art classes in schools has increased and a social campaign "Music develops well-rounded people - buy your child an instrument" was launched. As part of cooperation between cities, joint creativity-related initiatives have been intensified, such as participation of Polish cities in international Creative Cities Networks (Namyślak, 2014). As regards cooperation between entities, clusters started to be created to bring together representatives of various creative environments not previously linked by economic relations of this type (Bialic-Davendra, Bednář, Danko \& Matošková, 2016; Namyślak, 2019; ŚrodaMurawska \& Szymańska, 2013). Another new trend is the increasingly frequent restoration of degraded facilities, including former industrial sites, and their adaptation for the cultural sector (Murzyn-Kupisz, 2016). All these activities have one goal, which is to raise public cultural awareness and to help increase the significance and to improve the condition of the cultural sector.

\section{Infrastructure of the cultural sector in Wrocław \\ Subject matter of the research}

The analysis was performed for Wrocław - the capital of the Lower Silesian (Dolnośląskie) voivodeship (NUTS 2). As the largest city in the region, Wrocław serves as its economic, cultural and academic hub. One of the new trends observed in Wrocław is the ambition to create culture whose reputation would spread beyond Poland. In 2016, the city was named the European Capital of Culture ${ }^{2}$, which contributed to the improvement of cultural infrastructure, brought a significant increase in the number of cultural events and increased public participation in culture. Among others, the National Forum of Music was built as a greenfield project as well as the Academy of Fine Arts. Buildings

\footnotetext{
2 Although opinions on the permanent effects of hosting the ECC 2016 are divided (Świętochowska, Gubański \& Wojnar, 2015).
}

housing theatres, cinemas, community centres and artistic schools of various levels have been upgraded. A thriving network of municipal libraries has been created, including one at the central railway station. The number of regular cultural events has increased significantly, most of which (over 30) are musical events. In 2019, Wrocław was designated as a UNESCO City of Literature. All the above initiatives have significantly improved the cultural infrastructure, especially its publicly-funded part.

\section{Research Methods}

The paper focuses on entities which, according to the definition by DCMS (2013) form part of the cultural sector. The list of activities selected in the above way was translated into the categories from the Polish Classification of Activities. In this way, five categories were selected from two economy sectors to become the subject of this study. They are: publishing (J.58), film and music (J.59), radio and television (J.60), artistic activity (R.90) and culture and heritage (R.91).

The collected figures come from the National Official Registry of National Economy Entities (REGON) database managed by the Statistics Poland (GUS). The selected group includes over 1800 entities meeting the prescribed criteria. Then, the entities in the set were characterised according to the number of employees, date of establishment and other basic features. The data covers the years 2010-2019.

The analysis was carried out for the city of Wrocław, divided into residential settlements designated in 1991 and defined in the resolution of the Wroctaw City Council No. $X X / 110 / 91$ as auxiliary units of the urban municipality (Fig. 2).

\section{Characteristics and geographical distribution of entities}

In 2019, there were 1,876 cultural sector entities in Wrocław. Businesses involved in publishing and artistic activities have the largest 


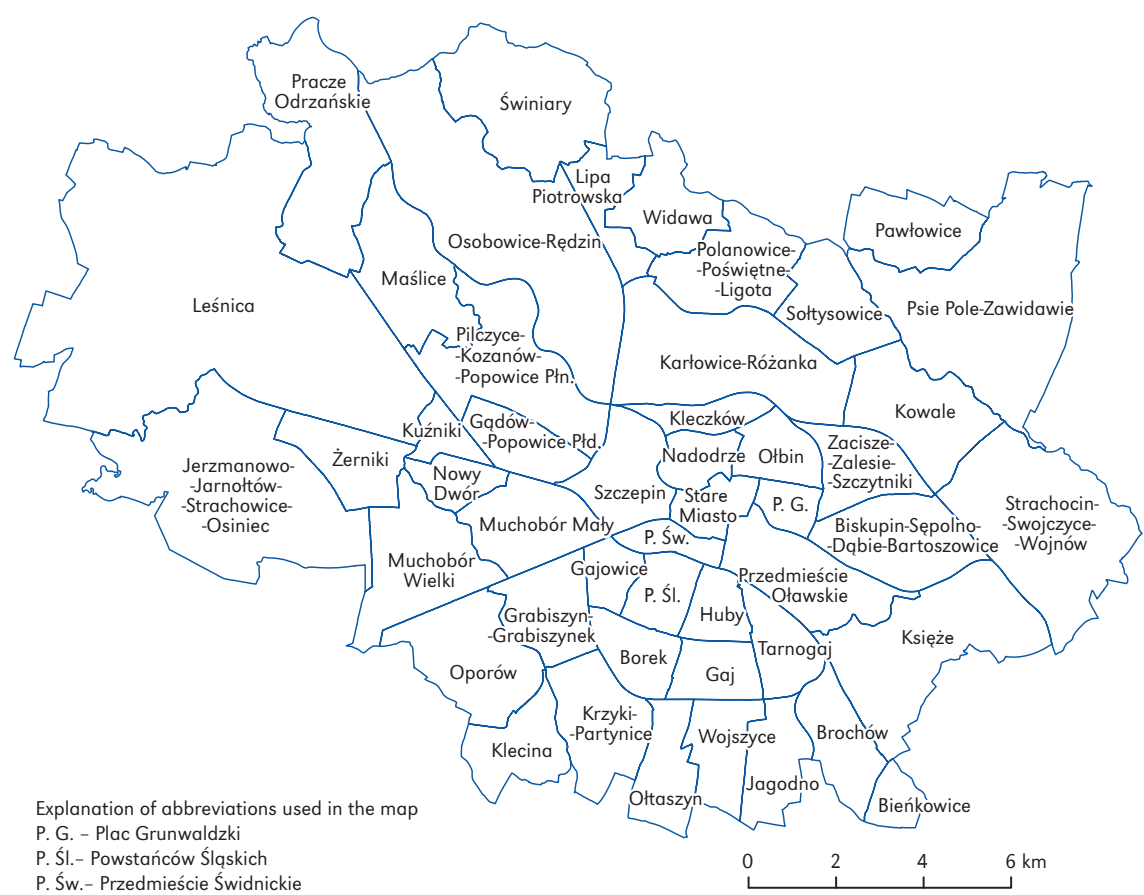

Figure 2. Administrative division of Wrocław

shares in the total number of entities $(32.9 \%$ and $34.9 \%$, respectively) (Tab. 1). The smallest number of entities represent national heritage and radio and TV. On the other hand, the period 2010-2019 witnessed the highest growth rate of film, music and artistic activities. In turn, the number of entities representing radio and television as well as publishing activities decreased in the above period. In general, however, in terms of numbers, cultural industries in Wrocław are growing. For example, by the end of September 2019, the number of newly registered entities was higher than in the corresponding period of 2018 (186 vs. 124). It should also be noted that the classification used by the Statistics Poland by type of business is disjoint, i.e. it classifies enterprises based on the prevailing type of activity. In reality, however, some entities offer a wide range of artistic services, such as music and film activities.

The predominant size of business in the studied group are micro enterprises employing up to 9 people. They constitute more than $96.5 \%$ of all enterprises, and together with small entities, with up to 49 employees - $99 \%$ of the total number (Tab. 2) 3 $^{3}$. Medium and large entities have very small shares, as low as $0.9 \%$ and $0.1 \%$, respectively. These shares slightly changed compared to 2010. The number of microenterprises went up, while the number of small enterprises (10-49 employees) went down. Entities with the highest employment represent primarily artistic activity and national heritage and are in the prevailing majority (18 out of 23) owned by local governments. In the small business group the proportions are different because the share of public ownership is much smaller and amounts to $33.3 \%$. However, in the group of micro-enterprises it is almost non-existent and amounts to only $0.4 \%$. In general, therefore, the cultural sector in Wrocław relies

\footnotetext{
3 These values are similar to the shares of all microand small enterprises in the total number of businesses in Wrocław which were respectively $96.3 \%$ and $2.9 \%$.
} 
Table 1. Change in the number of cultural sector enterprises in 2010-2019*

\begin{tabular}{|l|r|r|r|r|r|r|r|r|r|r|r|}
\hline \multirow{1}{*}{ Type of activity } & \multicolumn{10}{|c|}{ Number of cultural sector enterprises in Wrocław } \\
\cline { 2 - 12 } & 2010 & 2011 & 2012 & 2013 & 2014 & 2015 & 2016 & 2017 & 2018 & $2019 \star$ & $\begin{array}{c}2010 \\
=100 \%\end{array}$ \\
\hline Publishing & 671 & 664 & 684 & 693 & 689 & 666 & 678 & 688 & 650 & 655 & 97.6 \\
Artistic activity & 452 & 482 & 503 & 538 & 554 & 564 & 551 & 582 & 610 & 618 & 136.7 \\
Film, video, music activity & 296 & 299 & 300 & 316 & 376 & 390 & 424 & 439 & 465 & 480 & 162.2 \\
National heritage & 96 & 94 & 103 & 107 & 107 & 106 & 113 & 104 & 98 & 101 & 105.2 \\
Radio and television & 45 & 41 & 39 & 34 & 38 & 40 & 35 & 33 & 25 & 22 & 48.9 \\
\hline Total & 1560 & 1580 & 1629 & 1688 & 1764 & 1766 & 1801 & 1846 & 1848 & 1876 & 120.3 \\
\hline
\end{tabular}

* As at the end of September 2019

Source: Own study based on GUS data.

Table 2. Entities in the cultural sector in Wrocław by number of employees

\begin{tabular}{|l|c|c|c|c|}
\hline $\begin{array}{c}\text { Number } \\
\text { of employees }\end{array}$ & $\begin{array}{c}\text { Number of entities } \\
2010\end{array}$ & $\begin{array}{c}\text { Share } \\
{[\%] ~ 2010}\end{array}$ & $\begin{array}{c}\text { Number of entities } \\
2019^{\star}\end{array}$ & $\begin{array}{c}\text { Share } \\
{[\%] 2019}\end{array}$ \\
\hline Up to 9 & 1759 & 94.9 & 2237 & 96.5 \\
$10-49$ & 69 & 3.7 & 58 & 2.5 \\
$50-249$ & 23 & 1.3 & 21 & 0.9 \\
Above 250 & 2 & 0.1 & 2 & 0.1 \\
\hline Total & 1853 & 100.0 & 2318 & 100.0 \\
\hline
\end{tabular}

${ }^{\star}$ As at the end of September 2019

Source: Own study based on GUS data.

on medium and large publicly-funded entities and on privately-held micro-enterprises.

The share of foreign entities is negligent. It is undoubtedly a unique feature because in the majority of economic sectors in Poland, the presence of foreign capital is noticeable and in many of them dominant, as in the automotive or sugar industry or in trade or banking. In the analysed group, however, foreign companies are rare (2.6\%) and almost $40 \%$ of them represent the publishing sector. In 2010 the situation was similar, with foreign investors running only $1.8 \%$ of cultural sector enterprises.

The geographical distribution of cultural sector entities in Wrocław is uneven. A significant number of them are located along the southbound thoroughfare running from the city centre (Old Town) all the way to the southern boundary of the city. It is an area including such residential districts as Przedmieście Świdnickie, Borek, Powstańców Ślaskich, Krzyki-Partynice (Fig. 3). In total, around 25\% of all entities are located here. At the same time, the above residential districts have dense development, often including high-rise buildings, and have always been among the most expensive areas of the city. However, despite their large population, they are also areas with the highest number of cultural enterprises per 10,000 inhabitants (approx. 130140). Another observation is the predominance of entities located within $3 \mathrm{~km}$ from the Old Town and location of others in a few 


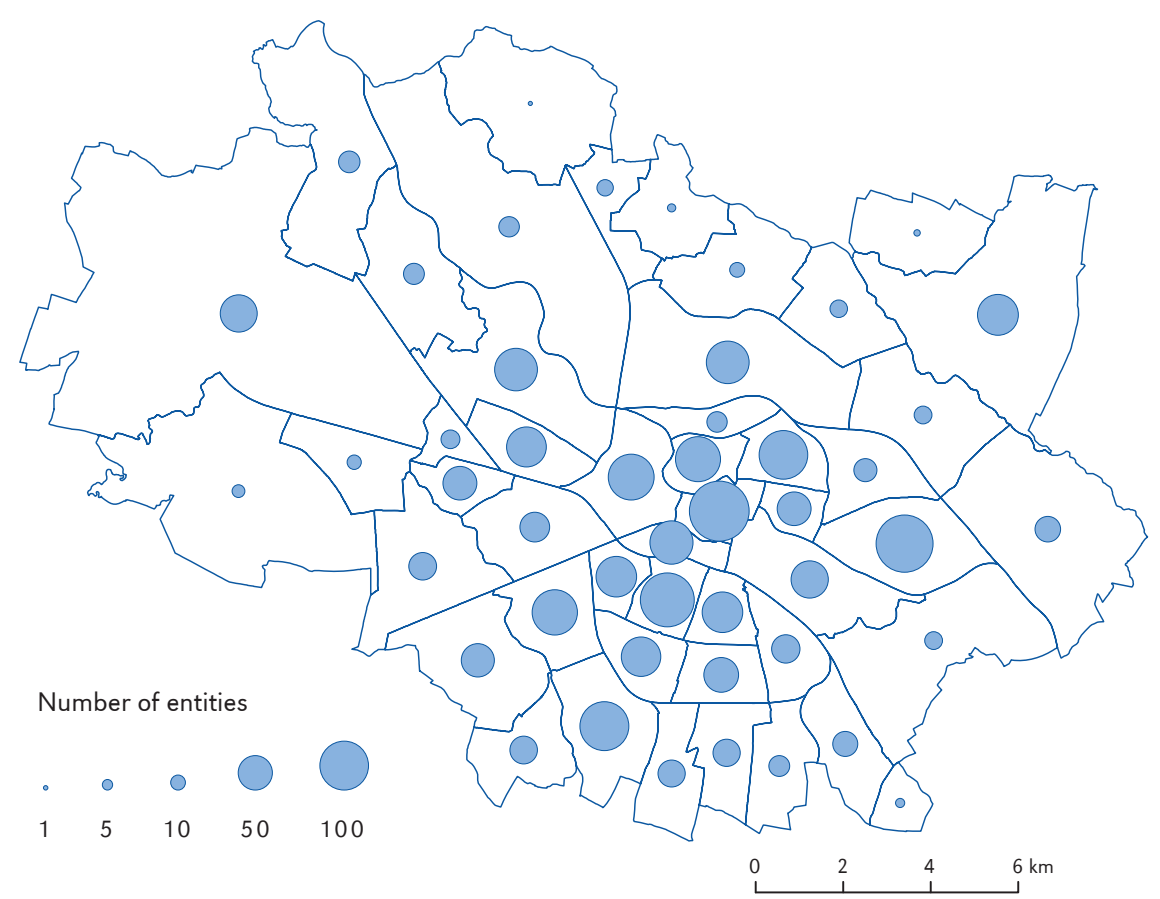

Figure 3. Geographical distribution of cultural sector enterprises in Wrocław

neighbourhoods away from the centre, mostly high-rise residential estates, such as Gąów-Popowice, Pilczyce-Kozanów or Karłowice-Różanka. Study findings show a strong relationship between the number of cultural enterprises and the number of inhabitants, which is a result of the fact that more than half of the entities (approx. 55\%), mainly micro-enterprises, are registered at private addresses (flats or houses) of their owners ${ }^{4}$.

Although the entire cultural sector in the city includes over 1,800 entities, it has not yet produced any permanent cluster structures. In 2011, efforts were made to launch the Creativro cluster consisting mainly of entities creating software and computer games. However, due to a lack of interest from local authorities, members began to withdraw from the initiative. In this case, the desired cooperation model aimed at strengthening

${ }^{4}$ The distribution of entities active in various sectors does not reveal any other regularities apart from the ones shown in Figure 2 presenting the entire group of the analysed entities. the interactions within the triple helix between three key actors: businesses, academic centres and local authorities did not find suitable conditions for growth. Ultimately, the initiative was dropped in $2016^{5}$. There are currently no cluster structures related to culture in Wrocław, or even more broadly, to creative industries.

\section{Cultural sector entities in Wrocław}

\section{Publishing activities}

The Polish publishing market is distinguished by a very high share of private ownership. In Wroctaw, this share stands at 99.7\%. The local publishing market consists of more than 655 entities involved in such activities as publishing of books (31\%), newspapers (5\%), magazines and other periodicals (14\%) and other publications (14\%), as well

\footnotetext{
5 Based on CAWI surveys conducted by the author in 2018 among creative cluster facilitators in Poland, which were described in the paper by Namyślak (2019).
} 
as computer games publishing (12\%) and software activities (24\%). Among well-known book publishers are Siedmioróg publishing books for children and young adults, Wiking specializing in school textbooks and atlases, Atut (publications about Lower Silesia) and university publishing houses. Wrocław is also home to Ossolineum - Poland's oldest publishing house (established in 1817). However, a general conclusion is that there are no large publishing houses printing high-volume books that could compete with renowned publishers in other parts of the country (the largest book publishers in Poland are located in Warsaw: Świat Ksiq̨żki, Reader's Digest, Wolters Kluwer, and Wydawnictwa Szkolne i Pedagogiczne. All of them are also wholly or mostly in foreign hands).

Publishers of magazines and other periodicals are mainly small and medium-sized companies, such as Motor Presse (publisher of automotive magazines and of Men's Health) and Phoenix Press (publisher of TV guides, crossword puzzles, children's and cooking magazines and self-help books). With the annual number of publications reaching almost 70 titles, Phoenix Press is the leader in the real life segment. Other companies in this category publish less popular magazines whose circulation does not exceed several thousand copies, while some magazines published by Motor Presse have a circulation of 60,000-80,000 copies and the best-selling Phoenix Press titles reach 800,000 copies: Przepisy Czytelników (Recipes from Readers) or Przepis na zdrowie (Recipie for Health). The largest two Wrocław dailies - Gazeta Wrocławska and Gazeta Wyborcza - are owned by publishers headquartered outside of Wrocław. Gazeta Wrocławska is in the hands of Polskapresse Publishing Group, which in turn is part of Verlagsgruppe Passau, a German media group. The publisher of Gazeta Wyborcza is Agora SA, a Warsawbased media group. In recent years, the circulation of both newspapers has been falling. The remaining companies are mainly micro-enterprises engaged in subcontracting jobs for the publishing business and offering publications of books, postcards, calendars, etc. They do not publish any periodical material. A general observation can be made that in the newspapers and magazines segment there is a lack of publishers with significant market shares (with the exception of Phoenix Press), and that the biggest demand is for less ambitious publications on cooking, self-help and TV guides.

As regards computer games publishing and software activities, the biggest employer (with a headcount of over 250) is Uni4Teta providing a wide range of programming services. Computer games publishing is also the only sector which is growing dynamically every year.

One of the ways to stimulate the growth of the local publishing sector is to increase the market by, for example, starting the sale of publications in super- and hypermarkets and in newsstands, to broaden the offer of e-books and audio books, and to launch new initiatives aimed at boosting interest in reading (Storytelling Festival). The falling circulation of print press is a result of the expansion of new media with which it is increasingly difficult for print press to compete.

\section{Film, video and music}

Wrocław's film and music sector comprises mainly the following activities: film production (73\% of entities), sound and music recording $(13 \%)$ and film post-production activities (11\%). In total, the sector includes 480 entities, with a predominant share of video filming companies and (mostly amateur) film studios, offering services for private parties (over 200 entities). The group of small enterprises includes mainly companies specialising in castings, advertising and promotional films, as well as businesses offering actor and extras casting and searching for locations for Polish and foreign films. Within this group, ATM Grupa SA is the most dynamically developing company and it is mainly involved in the production of television series (such as "Ranch" or "First Love"). Currently, ATM Grupa SA is Poland's largest independent TV producer and the only one in the sector 
to own technical facilities enabling the production of major television projects. ATM successfully licenses its programs to foreign customers, including to New Zealand, Italy, Greece, the Czech Republic or Ireland. It exchanges TV formats with producers from Denmark, Sweden, Great Britain, the U.S., Spain, Argentina and Germany.

As regards the production of feature films and television series, mention should be made of the Feature Film Studio (WFF) in Wrocław, which until recently was one of Poland's largest film studios. WFF played a major role in the development of Polish film in the 1950s and 1960s, the so-called golden age of Polish cinema. Nearly 430 feature films were made here, including works that went down in the history of Polish cinema, including "Ashes and Diamonds" (directed by A. Wajda), "Knife in the Water" (directed by R. Polański), "The Saragossa Manuscript" (directed by W.J. Has). Unfortunately, the beginning of political transformation brought a collapse of film production. In 2011, WFF was closed down and replaced by the Audiovisual Technology Center (CeTA) whose task was to disseminate innovative multimedia techniques.

Eight entities are involved in the distribution of films, video recordings and television programmes. The largest company in this category is Odra-Film - an institution of regional local government of the Lower Silesia voivodeship established in 1951. Its objects include the promotion of film culture as well as film distribution and production. In turn, post-production activities related to films, video recordings and television programmes (sound, special effects or editing) are only carried out by micro-enterprises that provide services to local producers as well as operate as subcontractors of producers from Warsaw.

A general observation is that the interest in domestic feature and documentary productions is on the rise. The is a growing significance of feature films, and some of them build the brand of the city and country abroad. The above creates the need to produce good, valuable films and to promote them effectively. Similarly to cities like Kraków, Wrocław's film producers struggle with strong competition from their peers based in Warsaw. Although in Wrocław the cost of film production is lower than in the capital, the problem remains. One can also mention the decrease in the number of cinemas, including the closures of art houses which are replaced by multiplexes, often located within shopping malls. As a result, the number of cinemas in Wroctaw has dropped, although the number of auditorium seats has increased. Wroctaw's cinematic reputation relies primarily on film festivals, such as "New Horizons Film Festival" or "American Film Festival" (the city does not have a film school). The above festivals feature a number of fringe events such as film retrospectives or thematic seminars, which are designed to increase interest in Polish and world cinema.

In the sphere of music Wrocław is represented by 60 entities, all of which are microenterprises. They create music score for films, theatre shows as well as for TV and radio commercials. There are also seven recording studios, six music producers and four concert agencies. In general, the number of entities is not large, despite the fact that Wroctaw is home to primary and secondary music schools as well as to the Academy of Music (tertiary level). Numerous (more than 30) music festivals are held to promote music (mainly classical). It should be mentioned, however, that along with the development of economic specialisations, the cultural policy of some Polish cities has focused on musical activity (e.g. the Silesian urban agglomeration) and in the future these cities may become strong players on the Polish music market.

\section{Radio and TV}

Television in Poland is characterised by a significant concentration of decision-making centres in Warsaw, as the largest television broadcasters and producers have their headquarters in the capital. Today, there are 18 entities of this type in Wrocław. However, 
only a few of them currently hold a licence to produce and broadcast programmes on regional or national stations. Wrocław Television, whose first programme went on air in 1962, has the longest history of them all. Currently, its programmes are broadcast on the local TVP Info band. Today, although TVP Wrocław employs almost 90 people and occupies an impressive building on one of Wrocław's thoroughfares, its programmes are not known to viewers across the country. The production of "With a Camera Among Animals", "Wheel of Fortune" or other quiz shows ended a couple or more years ago and no new shows appeared to replace them and which would have at least comparable viewership. Taking into account potential and existing facilities, it seems that among the most important challenges for Wrocław's cultural sector is to attract and enable the growth of entities involved in television activities. The task will be difficult due to falling viewing figures and the decreasing importance of television.

In line with the above trend, the number of radio broadcasters has decreased significantly and additionally, not all stations have a license to broadcast their own programmes. Radio Wrocław does hold such a licence. It has been in continuous operation since 1946 and employs almost 100 people (the remaining entities in this group are microenterprises). The station broadcasts its programme every day in Lower Silesia, in the neighbouring voivodeships and in the border areas of the Czech Republic and Germany. Other local radio stations are less popular, including the Students' Radio LUZ and the catholic "Radio Rodzina" (Radio Family).

A few other stations have a local licence, but they do not have any programme-related independence. For example, Radio Eska Wrocław broadcasts its own programmes only in the afternoon from $3 \mathrm{pm}$ to $6 \mathrm{pm}$, as well as local news and weather forecasts. The rest of the airtime is filled by broadcasts from other stations. This type of licence is also held by, among others, Radio Złote Przeboje. Usually - to satisfy licence requirements - only news services are produced in Wrocław together with programmes for drivers or late-night shows. According to SMG/KRC (PortalmedialnyPl, 2019), a survey institute offering surveys of radio station popularity, radio stations that broadcast all or almost all of their programmes from Wrocław have a small market share, e.g. Polish Radio Wrocław has only a 4\% share in the local market. Thus, it loses to Warsaw and Kraków tycoons like RMF FM, Radio Tok FM or Trójka - Polish Radio 3. Among the most popular stations in Wrocław is the Antyradio new regional radio station (6.1\%), which plays only rock music. It should also be added that among traditional media, radio has a constant number of listeners, which is a feature that distinguishes it from television and the press.

\section{Artistic activity}

The largest group of entities involved in artistic performances is composed of micro-enterprises (303 out of 326). These are mainly small theatres, art studios, concert agencies, music bands and impresarios. Larger companies are at the same time more prestigious institutions such as, for example theatres (CAPITOL Music Theatre, Contemporary Theatre, Puppet Theatre), Wratislavia Cantans festival office, Jerzy Grotowski Institute (successor to the Laboratory Theatre) (Fig. 4A), and the largest in the group (over 250 employees) National Forum of Music and the Wrocław Opera. In addition to their reputation, they also share a relatively long market presence, as the beginnings of their activity date back to the 1940s-1960s, with the exception of the National Forum of Music, which was established in 2014. They are all currently in the hands of local or regional government or the Ministry of Culture and National Heritage. In terms of numbers the group includes only a few entities, but each of them has a great impact on shaping the artistic tastes of Wrocław's residents. All the above institutions are supported by 113 microenterprises responsible for the management and promotion of artistic events, as well as for stage design, costumes and media relations services. 
Apart from entities involved in the production of artistic performances, there is a large group of companies dealing in artistic and literary creative activities. Their total number is 231 and all of them are micro-enterprises. These include primarily art studios and art galleries (glass, sculpture, painting, jewellery); the actual number of galleries is slightly larger, because more and more often they are created within larger institutions, such as shopping malls or pubs.

The third group of surveyed entities includes community centres and other cultural facilities. Their total number is 61 and they are located in different parts of the city. The biggest of them are two youth culture centres (MDK). Both centres are municipal government institutions devoted to cultural education of children and youth and to honing their interests. MDK's permanent offer includes: visual arts, including painting, drawing, graphics, weaving, photography, drama and music section: children's theatre and vocal ensembles. Each MDK has about 2,000 regular participants

Wrocław's significance in the field of artistic activity is shaped primarily by publicly funded institutions. Private entrepreneurs often face premises-related and financial problems. It should be added that in private theatres, actors and musicians are hired on a gig or one-off contract basis, so in reality the number of people involved in their activities is much larger.

One can observe several threats concerning further development of artistic activity in Wrocław. One of them is the belief that success can be achieved only in the capital or abroad, as a result of which too many talented artists leave Wroctaw. The number of performances on the local stages by foreign and domestic guest performers is also insufficient and the number of shows and concerts by Wrocław's cultural institutions on third-party stages is decreasing.

\section{National heritage}

The national heritage area is represented mainly by libraries, archives and museums.
The numbers of institutions are small (5, 13 and 7), but they employ relatively many people and have a significant impact on the city's cultural sector. The biggest libraries (with the exclusion of libraries within universities) are the Municipal Public Library with 44 branches (Fig. 4B), the Lower Silesia Pedagogical Library, whose branches are intended to serve primarily the educational community of the region and the Lower Silesian Public Library which has not only a collection of books and magazines, but stands out for its attractive cultural offer (meetings with creators, educational classes, workshops and more). The oldest library is Ossolineum with its collections related to the Polish history and literature. It features one of the largest book collections in Poland, as well as numerous manuscripts, including medieval prints, maps, medals and coins. Currently, this collection includes approximately 1,800,000 items. Gathering, storage, preparation and making available of archival materials is in turn the domain of archives, including the largest State Archives and several smaller ones, such as Municipal Archives (Fig. 4C) and Archives Company - a Repository of Files.

As for museums, the largest one is the City Museum of Wrocław, which was established as a result of merger of several smaller Wrocław museums, among others, The Historical Museum, The Museum of Bourgeois Art and Military Museum. Other noteworthy institutions include the National Museum and its two branches: Panorama of Racławice and The Ethnographic Museum whose main building hosts permanent exhibitions of Silesian art and Polish art. In addition, Wrocław is home to Poland's only Museum of Architecture and the only in the country Museum of Post and Telecommunications. The youngest museum, Wrocław Contemporary Museum (Fig. 4D) was established in February 2011. Museums that operate as parts of larger institutions (e.g. universities) are generally smaller than the ones mentioned above, they employ fewer employees and their collections are also smaller. These include The Museum of Man at the Department of Anthropology 

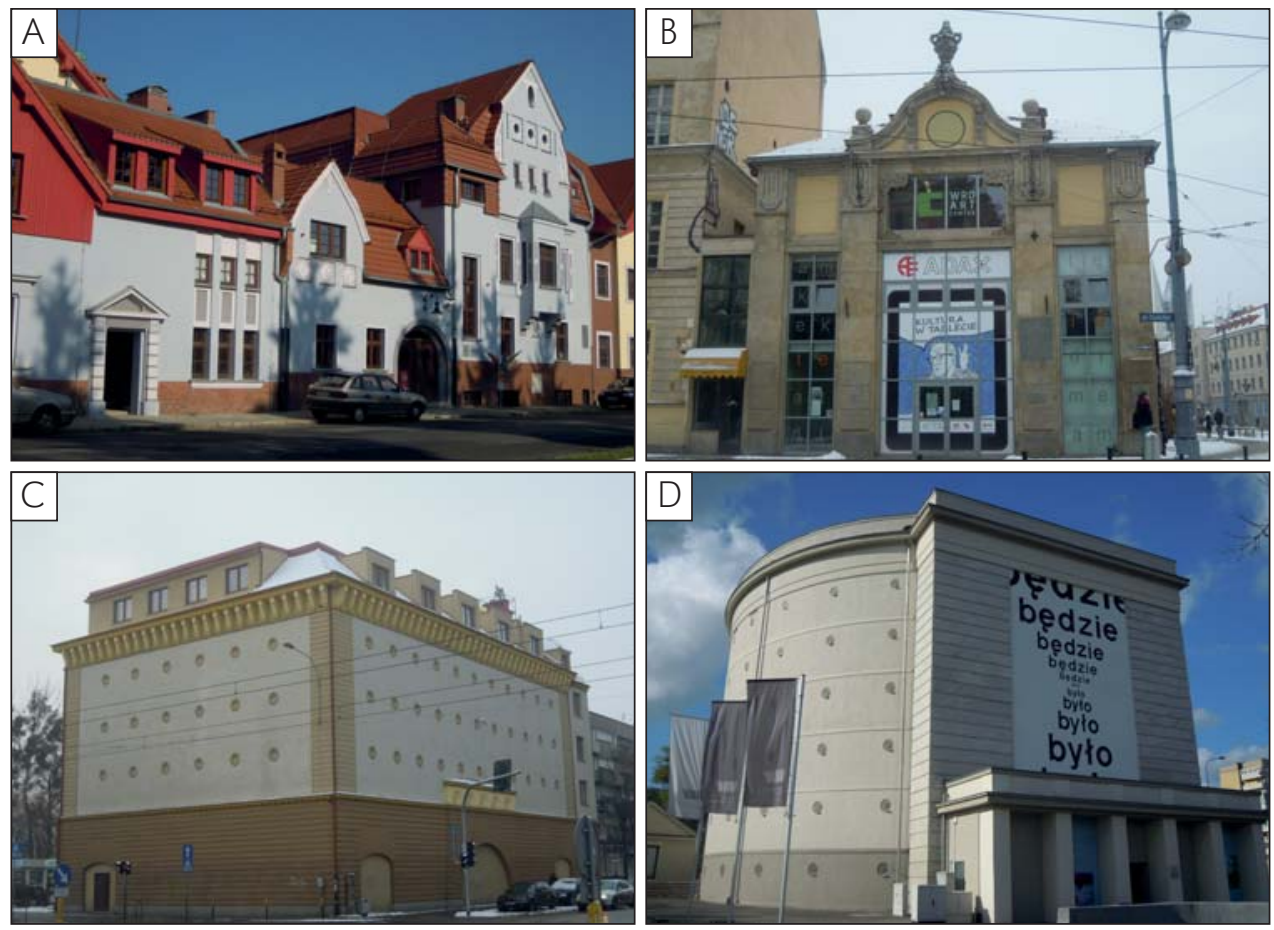

Figure 4. In recent years, some cultural entities in Wrocław were moved to or established in newly upgraded facilities: A - Jerzy Grotowski Institute in the former head office of Wratislavia Rowing Association (Na Grobli street); B - Mediateka - branch of Municipal Library (Teatralny square) in the former malthouse ("Siehdichfür"/Beware), later used as a coffee roasting plant, then a gym, C - the Municipal Archive (Stalowa street) was located in a former air-raid shelter; D - Wrocław Contemporary Museum (Strzegomski square) was also located in a former air-raid shelter.

of the University of Wroctaw and the Pan Tadeusz Museum, which is a branch of the Ossolineum. Its exhibits represent the era of European and Polish Romanticism.

The National Heritage group also includes entities dealing with the conservation of monuments, renovation of antiques, as well as archaeological works, stonework and sculpture (76). The visible fragmentation of the art restoration market is disadvantageous because it is accompanied by a weak position in the domestic and foreign markets resulting in a limited access to large orders at home or from abroad. In order to protect the national heritage, several programmes have been launched in the city regarding, for example, renewal of tenement houses ("100 Tenement Houses Programme"), adaptation of unused facilities for cultural purposes (museum in a former air-raid shelter, library in a former coffee roasting plant, etc., Figure 4A-D) and restoration of the former craft and commercial nature of Wrocław's Nadodrze neighbourhood ("Revitalisation of Old Trade Routes").

Some of the entities described in this section started operations before 1989. It is worth adding however that numerous restructuring processes took place over the 30 years of their existence. Generally, efforts were made to improve the cultural infrastructure, generate more initiatives and expand the cultural offer, to profile cultural institutions, as well as to rationalise the costs of maintaining their administration and facilities. In practice, the above translated into location changes (including moving the Ethnographic Museum in 2004 to smaller 
premises), the creation of new facilities to display previously inaccessible collections (e.g. Pan Tadeusz Museum - 2016, the "Zajezdnia" (Depot) History Centre - 2016, H. Tomaszewski Theatre Museum - 2017), reconstruction of existing facilities (e.g. Lower Silesian Film Centre - 2011) or their extension (e.g. CAPITOL Music Theatre - 2013), technical modernisation of facilities, but also liquidation of some entities (including the aforementioned Feature Film Studio and numerous arthouses and small local libraries).

\section{Discussion}

Cultural sector research was also conducted in other cities. It should be noted here however that the majority of studies relate to the creative industries as a whole, and thus their scope is slightly larger. Nevertheless, the author wishes to refer to some of them.

Stryjakiewicz and Stachowiak (2010) who studied creative activities in Poznań and its suburban area observed similarities (in comparison to the present study) in the structure of entities in terms of number of employees and a gradual (over the years) decrease in the number of large and medium-sized entities as well as the increase in the number of micro-enterprises. However, the analysis of details revealed some differences. For example, Poznań was dominated by artistic activity while Wrocław by publishing. Further observations can be made after reading the work of Dudek-Mańkowska, Fuhrmann, Grochowski and Zegar (2012) regarding Warsaw. The authors observed a wave increase in the number of creative sector entities culminating in 1996 and then in 2006-2008 (during the period of the highest GDP (\%) growth in Poland. The present author observed the opposite regularity for Wrocław. However, there is one feature that is common for all three cities (Poznań, Warsaw and Wrocław) it is a clear dominance of registration of entities from the analysed sector at home addresses. In addition to these general regularities, more specific observations can also be made. For example, Baran and Lewandowski
(2017), when analysing statistical data for the years 2008-2015 for the whole of Poland, observed a high development growth for the computer games segment and the same regularity is described in this paper. In contrast, Ratalewska (2018) pointed to the dominance of micro-enterprises in creative industries in Poland and the consequences resulting therefrom. This is also a characteristic observed in the capital of Lower Silesia. In turn, in her paper devoted only to small towns in Poland, Środa-Murawska (2013) described a decrease in the number of facilities providing cultural services, which proves that the position of the cultural sector in lowerranking towns is weaker than in metropolitan centres.

The literature also includes reports about the dominance of certain creative industries in urban centres. For example, in their study of London, Chapain and Stachowiak (2017) noted the dominance of the film industry, while Bader and Scharenberg (2010) pointed to the key role of the music industry in Berlin. The above can be a starting point for a discussion of economic specialisation of cities in individual creative industries. Some Polish cities/regions have already built such specialisations. For instance, the Silesian agglomeration decided to nurture music industry (Klasik, Drobniak, Wrana, 2009), Kraków focuses on cultural heritage (Murzyn-Kupisz, 2016), and Łódź continues to develop film art (Cudny, 2011). In the case of Wrocław, however, the dominance of any particular creative sector is not yet visible. Efforts are being made to develop the publishing segment and literature, but it is too early to conclude that it has already become the city's specialisation.

The implementation of the entire creative city model is a difficult task. Conditions that should be met by a city to be creative are described in the previous sections. Nevertheless, some cities decided to implement this model; among them are both European metropolises such as Berlin (Colomb, 2012) and cities of a lower rank like Meybod (Iran) (Kashkouli, Zarabi, \& Mousavi, 2018). The individual development paths are different. 
For example, Murzyn-Kupisz and Działek (2017) point to the role of artistic districts which create an additional opportunity for synergy in the artistic environment. No such district has been formed in Wrocław. Other cities treat the development of creative industries, including the cultural sector, as a panacea for economic development problems. Therefore, they restructure and revitalise cultural sector entities. These types of processes are particularly characteristic of the cities of the former Eastern Bloc. For example, Ponzini and Rossi (2010) or Vivant (2013) described transformations of urban landscapes filled with empty or degraded spaces for use by creative industries, with such processes also being observed in Wrocław. Analyses were also carried out to determine which entities participate most intensively in shaping the city's cultural policy. For example, Hausner, Malczyk, Maźnica, and Strycharz (2015) concluded that they were primarily municipal cultural institutions. In Wrocław, however, it would rather be a wider range of public and private entities.

\section{Final conclusions}

The development of the cultural sector in Wrocław has several important characteristics. After years of inertia, filmmaking is in the process of restructuring. Musical activity is focused on classical music, which is evidenced by the number of musical events or by the activity of cultural institutions. Currently, the main focus is on publishing activities which is a result of, among others, Wrocław's having been named UNESCO Creative City in the field of literature. In general, it must be noted that each of the analysed activities has both its strengths and weaknesses. Each one has its own opportunities and threats. It should also be added that the impact of culture on the economy does not need to happen at the same pace as it does on social changes. For example, the number of prestigious artistic institutions is not very large, but their influence on shaping social attitudes is perhaps the greatest.
Based on the information collected, the following conclusions can be made regarding the condition and outlook for Wrocław's cultural sector:

Micro-enterprises prevail in the analysed set of more than 1800 entities from the cultural sector. This is in line with the trends described in the literature on the subject, because the cultural and creative industries in general are characterised by a dominance of very small entities. For example, in Wrocław, the most numerous group of publishing companies does not include large entities at all, there are only 3 medium-sized enterprises, 27 small and as many as 625 micro-enterprises. This is largely a result of the nature of the work, which is predominantly individual work. As compared with other types of economic activity, there is a clearly larger share of micro- and small enterprises, including sole proprietorships. It is also a consequence of the lack of big investors, including international ones. The largest entities are usually run by local/ regional authorities or by the Ministry of Culture and National Heritage.

Recent years, especially the period 20162019, have witnessed a notable increase in the number of cultural entities. This increase was particularly conspicuous in the new media sector, including computer games publishers. As a matter of fact, this is the only one among the studied sectors in which the number of new entities has been growing each year. The author has tried to establish a correlation between the date of establishment of the surveyed companies and GDP growth rates measured as a percentage. However, the correlation between the date of establishment of cultural sector entities and GDP (\%) is very weak and amounts to $\left(R_{x y}=-0.125\right)$. It is therefore negative. In the years in which GDP grew less than 2\% (2001, 2002, 2012, 2013) the number of entities in the cultural sector was on the rise; on the other hand, the periods in which Poland recorded its highest GDP growth (1995-1997 and 2006-2007 when GDP growth exceeded $6 \%$ ) were not remarkable as regards the issue 
in question. Therefore, the establishment of entities in the field of culture is determined by other factors, including a general increase in the demand for this type of services and products in the recent period.

Among other noteworthy events is the winding up of Wrocław Feature Film Studio and the decline of TVP Wrocław. At the same time, we have been witnessing the growth of the Phoenix Press publishing house which has been successfully selling several dozen titles of newspapers and magazines about fashion or cooking, as well as of the ATM group, a producer of popular TV series. Therefore, looking at the above changes, one may conclude that contemporary trends and the demand for mass culture products have prevailed while the institutions offering more ambitious products have lost in this confrontation. It is also worth adding that in some areas, such as publishing of newspapers and books or broadcasting of television and radio programmes, there is very strong competition from entities (Polish and foreign) located in other cities, including Warsaw. Thus, the emergence in Wrocław of a new important player in the field of culture would be currently very difficult.

Cultural sector entities tend to be located in the vicinity of the Old Town, but also in high-rise housing estates as well as along the thoroughfare running from the city centre to the south, up to the border with Kobierzyce which is a particularly highly urbanised commune. However, the high presence of cultural sector companies in the city (Tab. 1 and Fig. 2) did not translate into the creation of cluster structures which have been popular in recent years in Poland. In 2011 an attempt was made to launch a cluster including software and computer game publishers but after several years of inertia the initiative was dropped. There are currently no cluster structures related to culture in Wrocław, or even more broadly, to creative industries.

It is very difficult to plan the future in cultural development. Nevertheless, based on the collected data, it seems that the increase in the number of new entities in this segment will continue. Therefore, further research on the condition and directions of culture development seems all the more important. In the near future, the author plans to study the regularities in the distribution of creative activities and to analyse creative clusters against the background of other cluster structures in the country.

\section{Acknowledgments}

The paper was based on a study funded by the National Science Centre as part of the project titled "Organisation of relationships in creative clusters as a regional and local development factor" (Project No. 2017/25/B/ HS4/00098).

Editors' note:

Unless otherwise stated, the sources of tables and figures are the authors', on the basis of their own research.

\section{References}

Bader, I. \& Scharenberg, A. 2010. The sound of Berlin: Subculture and the global music industry. International Journal of Urban and Regional Research, 34(1), 76-91. https://doi.org/10.1111/j.1468-2427.2009.00927.x

Baran, J., Lewandowski, P. (2017). Znaczenie gospodarcze sektora kultury w Polsce w latach 2008-2015. Warszawa: Instytut Badań Strukturalnych.

Bialic-Davendra, M., Bednář, P., Danko, I., Matošková, J. (2016). Creative clusters in Visegrad Countries: Factors conditioning cluster establishment and development. Bulletin of Geography. Socio-economic Series, 32, 33-47. https://doi.org/10.1515/bog-2016-0013. 
Blaug, M. (2001). Where are we now on cultural economics? Journal of Economic Surveys, 15(2), 123-143. https://doi.org/10.1111/1467-6419.00134

Chapain, C. \& Stachowiak, K. (2017). Innovation dynamic in the film industry: The case of the Soho Cluster in London. In C. Chapain \& T. Stryjakiewicz (Eds.), Creative industries in Europe. Drivers of new sectoral and spatial dynamics (pp. 65-94). Cham, Switzerland: Springer International Publishing AG. https://doi.org/10.1007/978-3-319-56497-5_4

Colomb, C. (2012). Pushing the urban frontier: Temporary uses of space, city marketing, and the creative city discourse in 2000s Berlin. Journal of Urban Affairs, 34(2), 131-152. https://doi.org/10.1111/j.1467-9906.2012.00607.x

Cooke, P. \& Porter, J. (2011). Media convergence and co-evolution at multiple levels. City, Culture and Society, 2(2), 101-119. https://doi.org/10.1016/j.ccs.2011.05.004

Cudny, W. (2011). Film festivals in Łódź as a main component of urban cultural tourism. Bulletin of Geography. Socio-economic Series, 15, 131-141. https://doi.org/10.2478/v10089-011-0009-6

Department for Culture, Media and Sport (2013). Classifying and measuring the creative industries. London [PDF document]. Retrieved from https://assets.publishing.service.gov.uk/government/uploads/ system/uploads/attachment_data/file/203296/Classifying_and_Measuring_the_Creative_Industries_Consultation_Paper_April_2013-final.pdf

Dudek-Mańkowska, S., Fuhrmann, M., Grochowski, M., Zegar, T. (2012). Sektor kreatywny a przestrzenie publiczne w Warszawie (Creative sector versus public space in Warsaw). Mazowsze. Studia Regionalne, 11, 147-157.

Evans, G. (2009). Creative cities, creative spaces and urban policy. Urban Studies, 46(5/6), 1003-1040. https://doi.org/10.1177/0042098009103853

Florida, R. (2002). The rise of the creative class. New York: Basic Books (translation: Florida, R. (2010). Narodziny klasy kreatywnej. Warszawa: Narodowy Instytut Kultury).

Flew, T., Cunningham, S. (2010). Creative industries after the first decade of debate. The Information Society, 26(2), 113-123. https://doi.org/10.1080/01972240903562753

Flew, T. (2013). Global creative industries. Cambridge: Polity Press.

Garnham, N. (2005). From cultural to creative industries. International Journal of Cultural Policy, 11(1), 15-29. https://doi.org/10.1080/10286630500067606

Gibson, Ch. (2010). Cultures at work: Why 'culture' matters in research on the 'cultural' industries. Social and Cultural Geography, 4(2), 201-215. https://doi.org/10.1080/14649360309059

Hausner, J., Malczyk, K., Maźnica, Ł., \& Strycharz, J. (2015). Diagnoza potencjału podmiotów kultury w zakresie realizacji Programu Rozwoju Kultury 2020 (Diagnosis of the potential of cultural entities in implementing the 2020 Culture Development Program). Kraków: Fundacja GAP.

Hospers, G.J. (2003). Creative cities: Breeding places in the knowledge economy. Knowledge, Technology \& Policy, 16(3), 143-162. https://doi.org/10.1007/s12130-003-1037-1

Jankowska, B. (2012). Koopetycja w klastrach kreatywnych (Coopetition in creative clusters). Poznań: Wydawnictwo Uniwersytetu Ekonomicznego w Poznaniu.

Kacprzak, A., Dziewianowska, K., Skorek, M. (2015). Gospodarka doświadczeń. Perspektywa polskiego konsumenta (Experience economy. Perspective of the Polish consumer). Warszawa: Wydawnictwo PWN.

Kashkouli, A.B., Zarabi, A., Mousavi, M.N. (2018). The role of creative economy in the realization of a creative city: A case study of the city of Meybod in Yazd Province, Iran. Geographia Polonica, 91(3), 335-351. https://doi.org/10.7163/GPol.0124

KEA (2006, October). The economy of culture in Europe. Study prepared for the European Commission [PDF document]. Brussels: European Commission. Retrieved from https://ec.europa.eu/assets/eac/culture/library/studies/cultural-economy_en.pdf 
Klasik, A., Drobniak, A. \& Wrana, K. (2009), Perspektywy rozwoju aglomeracji górnoślaskiej na podstawie sektora gospodarki kreatywnej (Development prospects for the Upper Silesian agglomeration based on the creative economy sector). Biblioteka Regionalisty, 9, 55-76.

Klasik, A. (2011). The culture sector and creative industries as a new foundation of development of large cities and urban agglomerations. In A. Klasik (Ed.), The cities and agglomerations development based on the culture sector and creative industries (pp. 14-41).Warsaw: Polish Academy of Science.

Kong, L. (2000). Culture, economy, policy: Trends and developments. Geoforum, 31(4), 385-390. https://doi.org/10.1016/s0016-7185(00)00004-x

Kościelecki, P. (2007). Kultura w regionach - analiza dokumentów strategicznych polskich województw oraz piśmiennictwa przedmiotu (Culture in regions. Overview of the strategic documents of Polish voivodships and academic literature). Studia Regionalne i Lokalne, 3(29), 32-52.

Kultura w 2016 roku (Culture in 2016). (2017). Warszawa: Główny Urząd Statystyczny (Statistics Poland).

Kultura w 2017 roku (Culture in 2017) (2018). Warszawa: Główny Urzad Statystyczny (Statistics Poland).

Kultura w 2018 roku (Culture in 2018) (2019). Warszawa: Główny Urzad Statystyczny (Statistics Poland).

Landry, C. (2008). The creative city: A toolkit for urban innovators (2nd edition). London: Earthscan Publishing.

Murzyn-Kupisz, M. (2016). Instytucje muzealne z perspektywy ekonomii kultury (Museum institutions from the perspective of the economics of culture) (in cooperation with: J. Działek). Kraków: Universitatis.

Murzyn-Kupisz, M., Działek, J. (2017). Do artists need artistic quarters? Spatial preferences and choices of artists in Krakow. In M. Murzyn-Kupisz, J. Działek, J. (Eds.), The impact of artists on contemporary urban development in Europe (pp. 91-120). Cham: Switzerland: Springer International Publishing AG. https://doi.org/10.1007/978-3-319-53217-2_4

Namyślak, B. (2014). Cooperation and forming networks of creative cities: Polish experiences. European Planning Studies, 22(11), 2411-2427. https://doi.org/10.1080/09654313.2013.843652

Namyślak, B. (2019). Klastry w sektorze kreatywnym w Polsce (Clusters in the creative sector in Poland). Studia Regionalne i Lokalne, 78(4), 95-114. https://doi.org/10.7366/1509499547805

Pine, B.J., Gilmore, J.H. (2013). The experience economy: Past, present and future. In J. Sundbo, F. Sørensen (Eds.), Handbook on the experience economy (pp. 21-44). Edward Elgar Publishing. https://doi.org/10.4337/9781781004227.00007

Ponzini, D., Rossi, U. (2010). Becoming a creative city: The entrepreneurial mayor, network politics and the promise of an urban renaissance. Urban Studies, 47(5), 1037-1057. https://doi.org/10.1177/0042098009353073

PortalmedialnyPL (2019, February 27). Wrocław: RMF FM liderem, TOK FM w górę. (Wrocław: RMF FM is the leader, TOK FM up) (Report). Retrieved from http://www.portalmedialny.pl/art/67908/wrocaw-rmf-fm-liderem-tok-fm-w-gore.html.

Power, D. (2011). Priority sector report: creative and cultural industries. The European Cluster Obligatory. Europa Innova Paper, 16 [PDF document]. Brussels: European Commission. Retrieved from http://volanteresearch.com/wp-content/uploads/2014/03/ECO-2011.pdf

Pratt, A.C. (2008). Creative cities: The cultural industries and the creative class. Geografiska Annaler: Series B: Human Geography, 90(2), 107-117. https://doi.org/10.1111/j.1468-0467.2008.00281.x

Ratalewska, M. (2018), The role of entrepreneurship and business consulting in companies in creative industries. Problemy Zarzadzania, 16(1), 181-191. https://doi.org/10.7172/1644-9584.73.11

Stachowiak, K. (2017). Gospodarka kreatywna i mechanizmy jej funkcjonowania. Perspektywa geograficzno-ekonomiczna (Creative economy and mechanisms of its functioning. A geo-economic perspective). Poznań: Bogucki Wydawnictwo Naukowe.

Stryjakiewicz, T., Stachowiak, K. (2010). Sektor kreatywny w poznańskim obszarze metropolitalnym. Tom 1 (Creative sector in the Poznań metropolitan area. Vol. 1). Poznań: Bogucki Wydawnictwo Naukowe. 
Stryjakiewicz, T., Męczyński, M., Stachowiak, K. (2014). Role of creative industries in the post-socialist urban transformation. Quaestiones Geographicae, 33(2), 19-35. https://doi.org/10.2478/quageo-2014-0013

Środa-Murawska, S. (2013). Usługi kulturalne w małych miastach (Cultural services in small cities). Wiadomości Statystyczne, 11, 37-51.

Środa-Murawska, S., Szymańska, D. (2013). The concentration of the creative sector firms as a potential basis for the formation of creative clusters in Poland. Bulletin of Geography. Socio-economic Series, 20, 85-93. https://doi.org/10.2478/bog-2013-0013

Świętochowska, A., Gubański, K., Wojnar, K. (2017). Ekonomia prestiżu w obiegach metakultury. Wrocławskie środowiska i instytucje kulturalne po doświadczeniu Europejskiej Stolicy Kultury. Kultura Współczesna, 5, 124-139.

Throsby, D. (2008). Modelling the cultural industries. International Journal of Cultural Policy, 14(3), 217232. https://doi.org/10.1080/10286630802281772

Towse, R. (2010). A textbook of cultural economics. Cambridge: Cambridge University Press.

Trip, J.J., Romein, A. (2014). Creative city policy and the gap with theory. European Planning Studies, 22(12), 2490-2509. https://doi.org/10.1080/09654313.2013.790592

UNESCO (2009). Framework for cultural statistics. Montreal: UNESCO Institute for Statistics.

Retrieved from

http://uis.unesco.org/sites/default/files/documents/unesco-framework-for-cultural-statistics-2009-en_0.pdf.

Vivant, E. (2013). Creatives in the city: Urban contradictions of the creative city. City, Culture and Society, 4(2), 57-63. https://dx.doi.org/10.1016/j.ccs.2013.02.003 